\title{
Psychological Attribution Analysis of Medical College Students Skipping Classes
}

\author{
Jieping Zhang, Yao Wu, Zhangyao Li, Xueqin Zhou, Shudan Feng *, \\ Xiaoyan Cao
}

School of Humanities and Management, Southwest Medical University, Luzhou, Sichuan, 646000, PRC, China.

${ }^{*}$ Corresponding author: Shudan Feng

Keywords: full-time e, Southwest, in your paper; students skipping.

\begin{abstract}
In recent years, some data about college students skipping classes showed that the truancy of college students has become a prominent teaching problem which commonly exists. By collecting problems of full-time medical students of the Southwest Medical University to master the situation of students skipping classes, the author conducts attribution analysis and puts forward some corresponding countermeasures, hoping to provide reference for the school's management and related institutions and thereby improving the quality of teaching in schools.
\end{abstract}

\section{Introduction}

It is a common phenomenon that college students skip classes. According to the survey data, $9.76 \%$ of the surveyed contemporary college students thought that "only $20 \%$ of students have skipped classes"; $9.42 \%$ of them sated "half of students have skipped classes" and $58.92 \%$ argued that "more than $80 \%$ of students have skipped classes". It is worth mentioning that, $24.92 \%$ of the surveyed students thought that " $100 \%$ of students have skipped classes".

It can be seen that the behavior of skipping classes is common in colleges and universities, and the truancy rate also increases with the grade. There is a popular saying: freshmen are "trainees" and they occasionally skip classes through eyeing the opportunity; sophomores are "skilled workers" and they skip classes when it is needed; juniors and seniors are "old foxes" and they skip classes when they want. The truancy rate of college students was $12.4 \%$ in their first year and $24.3 \%$ in the second year; and this rate was $50.5 \%$ in graduating classes. It can be seen that the truancy rate in graduating classes was significantly higher than that of the other grades.

Teaching is an important link to ensure the quality of school teaching. That students skip classes seriously hinders the normal development of teaching work in colleges and universities, and it also affects the improvement of college Students' comprehensive ability of professional knowledge and quality. Therefore, college students' truancy has become an important problem that cannot be ignored in the teaching and management of colleges and universities.

After consulting the relevant literature, the skipping class can be interpreted as a kind of truancy behavior, that is, students do not take classes according to the prescribed time and place without asking for leave. It is a kind of behavior that avoids classes.

Psychological attribution: Attribution refers to the process that a person analyzes behaviors of his own and other people, points out the causes of these behaviors and attitudes, controlling his nature and environment and thereby deduces or predicts the behaviors and attitude of his own and others. Psychological attribution is the explanation and deduction of human behavior and attitude from the perspective of psychology.

\section{Objects and Methods}

\subsection{Research Objects}

The questionnaire survey was conducted at the Southwest Medical University in October 2015.In this survey, 1000 students were randomly selected as objects of the research and the recovery rate was 
$100 \%$.The number of effective questionnaires was 499 , with an effective recovery rate of $49.9 \%$.The respondents included 178 boys, accounting for $35.7 \%$ of the total number of subjects; the number of girls was 321, accounting for $64.3 \%$.

\subsection{Research Methods}

This research adopts the method of quantitative research. According to the purpose of the survey, the questionnaire (Questionnaire about College Students' Psychology of Skipping Classes) was compiled on the basis of relevant theories and other people's questionnaires. The questionnaire covers contents of various aspects, including the respondents' gender, specialty, actual situation of skipping classes, attitude towards skipping classes, the course that they often play truant from, the reason for truancy, efforts that the school, teachers and themselves should make to reduce truancy, aiming at exploring students' psychology of skipping classes through the analysis of these issues. The teachers and students who had received formal training gave out and received the questionnaires after school hours, and respondents filled the questionnaire anonymously and voluntarily.

\subsection{Statistical Processing}

SPSS 21.0 was adopted for statistical analysis and $\mathrm{P}<0.05$ meant statistical significance.

\section{Result}

\subsection{Rate of Truancy}

Table 1 the rate of truancy during the school period $n,(\%)$

\begin{tabular}{|c|c|c|c|c|}
\hline Item & Never & Hardly ever & Sometimes & Often \\
\hline $\begin{array}{c}\text { Have you ever skipped } \\
\text { classes at school? }\end{array}$ & $44(8.8)$ & $244(48.9)$ & $204(40.9)$ & $7(1.4)$ \\
\hline
\end{tabular}

As shown in the Table 1, the number of students who had never skipped classes during the period of school was only 44, accounting for $8.8 \%$; 244 students hardly ever skipped classes, accounting for 48.9\%; 204 students skipped classes sometimes, accounting for $40.9 \%$, which was equal to the number of students who hardly ever skipped classes; the number of students who often played truant from classes was 7 , accounting for $1.4 \%$.It can be seen that $91.2 \%$ of students attending the random survey had the experience of skipping classes. But only a few students often skipped classes, and most students did not skip classes or sometimes skipped classes.

\subsection{Courses Those Students Often Played Truant From}

Table 2 the courses that students often played truant from n, (\%)

\begin{tabular}{|c|c|c|c|c|c|c|c|}
\hline \multirow{2}{*}{\multicolumn{2}{|c|}{ Item }} & \multicolumn{6}{|c|}{ Courses } \\
\hline & & $\begin{array}{l}\text { Ideological and } \\
\text { Moral Cultivation } \\
\text { and Legal Basis, } \\
\text { Marxist philosophy } \\
\text { Principles and } \\
\text { other basic courses }\end{array}$ & English & $\begin{array}{l}\text { Elective } \\
\text { courses }\end{array}$ & $\begin{array}{c}\text { Specialized } \\
\text { courses }\end{array}$ & $\begin{array}{l}\text { Common } \\
\text { required } \\
\text { courses }\end{array}$ & $\begin{array}{l}\text { Depending } \\
\text { upon the } \\
\text { actual } \\
\text { situation }\end{array}$ \\
\hline \multirow{2}{*}{$\begin{array}{l}\text { Did you ever } \\
\text { play truant from } \\
\text { these courses? }\end{array}$} & Yes & $65(13)$ & $14(2.8)$ & $292(58.5)$ & $7(1.4)$ & 49 (9.8) & 251 (43.1) \\
\hline & No & 434 (87) & $486(97.2)$ & $207(41.5)$ & 492 (98.6) & $454(90.2)$ & 284 (56.9) \\
\hline
\end{tabular}

As shown in Table 2, there were 292 people who often played truant form elective courses, accounting for $58.5 \%$ of the total respondents; $43.1 \%$ of the respondents, namely 251 students, decided to whether skipped a class or not according to the actual situation, and this number is only second to the number of truancy in elective courses; the courses that students often played truant from were basic courses such as Ideological and Moral Cultivation and Legal Basis and Marxist philosophy Principles, followed by common required courses and English, respectively accounted for $13 \%, 9.8 \%$ and 2.8\%; Specialized courses held the lowest truancy rate, only accounting for $1.4 \%$.Thus, elective courses bore the highest rate of truancy and there was also great probability that 
students might play truant from these courses when they need or want. 98.6\% of the students did not choose to play truant from specialized courses.

\subsection{What Do You Do After Skipping Class}

Table 3 what do you do after skipping class n, (\%)

\begin{tabular}{|c|c|c|c|c|c|c|c|c|}
\hline \multicolumn{9}{|c|}{ Item } \\
\hline \multirow{3}{*}{$\begin{array}{l}\text { What do you do after } \\
\text { skipping class }\end{array}$} & & Sleeping & $\begin{array}{l}\text { Study by } \\
\text { yourself }\end{array}$ & $\begin{array}{l}\text { Playing } \\
\text { games }\end{array}$ & Dating & $\begin{array}{c}\text { Daily } \\
\text { entertainment }\end{array}$ & $\begin{array}{c}\text { Other proper } \\
\text { business of work }\end{array}$ & Others \\
\hline & Yes & $\begin{array}{c}141 \\
(28.3)\end{array}$ & 149 (29.9) & 45 (9.0) & $12(2.4)$ & 75 (15.0) & 275 (55.1) & $\begin{array}{c}100 \\
(20.0)\end{array}$ \\
\hline & No & $\begin{array}{c}358 \\
(71.7)\end{array}$ & $350(70.1)$ & 454 (91.0) & $\begin{array}{c}487 \\
(97.6)\end{array}$ & $424(85.0)$ & 224 (44.9) & $\begin{array}{c}399 \\
(80.0)\end{array}$ \\
\hline
\end{tabular}

As shown in Table 3, 275 of the students did other proper business after skipping classes, accounting for about 55.1\%; students who studied by themselves and slept after skipping classes kept similar percentages, accounting for $29.9 \%$ and $28.3 \%$ respectively; 75 students chose daily entertainment, accounting for about $15 \%$; respondents who chose playing games accounted for $9 \%$; only $2.4 \%$ of the student dated after skipping classes and $20 \%$ of the students did other things. Thus, after skipping classes, about half of the students did other proper business; about 1/3 of them chose to sleep or study by themselves; some students did other things or entertainment activities, and a very small number of students played games or dated.

3.4 The Relationship Between Truancy and the Major, Gender and Whether Students Like Their Specialty or Not

Table 4 the correlation between truancy and the major, gender and whether students like their own specialty or not

\begin{tabular}{|c|c|c|}
\hline \multirow{2}{*}{ Item } & \multicolumn{2}{|c|}{ Did you ever play truant from these courses? } \\
\cline { 2 - 3 } & Pearson correlation & Significance p (2-sided) \\
\hline Major & $-0.0127^{* *}$ & 0.005 \\
\hline Gender & $-0.095^{*}$ & 0.034 \\
\hline $\begin{array}{c}\text { Do you like your } \\
\text { specialty? }\end{array}$ & $-0.094^{*}$ & 0.036 \\
\hline
\end{tabular}

(Note: * represents $\mathrm{p}<0.05, * *$ presents $\mathrm{p}<0.01$ )

It is shown in Table 4 that there is a correlation between truancy and the specialty, gender and whether the student likes his/her specialty or not, and the correlation coefficients respectively are -0.0127, -0.095 and -0.094 , which presents nonlinear correlation; there is a significant correlation between specialty and truancy at the level $\mathrm{p}=0.01$; there is a significant correlation between gender and truancy at the level $\mathrm{p}=0.05$; there is a significant correlation between whether a student likes his/her specialty and truancy at the level $\mathrm{p}=0.05$.Therefore, a conclusion can be drawn as follows: the phenomenon of skipping classes is common in every specialty of Medical Universities; both male and female students may skip classes and students may play truant from classes no matter they like their specialty or not. 


\subsection{Reasons for Truancy}

Table 5 Causes of truancy phenomenon $\mathrm{n},(\%)$

\begin{tabular}{|c|c|c|c|c|c|c|}
\hline \multicolumn{7}{|c|}{ Item } \\
\hline & $\begin{array}{l}\text { The course is } \\
\text { too simple to } \\
\text { attend classes }\end{array}$ & $\begin{array}{l}\text { The curriculum } \\
\text { is too difficult to } \\
\text { keep up with } \\
\text { and I am not } \\
\text { interested in it, } \\
\text { and thus I skip } \\
\text { classes as others } \\
\text { do. }\end{array}$ & $\begin{array}{c}\text { I skip class } \\
\text { because I } \\
\text { oversleep }\end{array}$ & $\begin{array}{c}\text { The teacher } \\
\text { never calls the } \\
\text { roll and it } \\
\text { doesn't matter if } \\
\text { I don't attend the } \\
\text { class }\end{array}$ & $\begin{array}{l}\text { The teacher's } \\
\text { lecture is too dull } \\
\text { to attract my } \\
\text { attention }\end{array}$ & Weather \\
\hline Yes & $130(26.1)$ & $104(20.8)$ & $97(19.4)$ & $170(34.1)$ & $263(52.7)$ & $51(10.2)$ \\
\hline No & 369 (73.9) & 395 (79.2) & $402(80.2)$ & 329 (65.9) & $236(47.3)$ & 448 (89.8) \\
\hline
\end{tabular}

As can be seen from table 5, 52.7\% of students held that teachers' boring lectures was the main reason for truancy, and only $10.2 \%$ of students regarded the weather as the reason for truancy;34.1\% of the students skipped classes because the teacher never called the roll;26.1\% of the students thought that the courses were too simple while $20.8 \%$ of the students thought the courses were too difficult to catch up with, and therefore, students may skip classes if a course is too easy or too difficult. $19.4 \%$ of the students took "oversleep" as the reason for truancy. Thus it can be understood that various factors should take the responsibility for the phenomenon of students skipping classes.

\subsection{The Efforts That Students Think the School, Teachers and the Student Themselves Should} Make

Table 6 Students' choice of the efforts to be made n, (\%)

\begin{tabular}{|c|c|c|}
\hline & Item & \\
\hline \multirow{4}{*}{ School } & Release a series of measures more severe & $41(8.2)$ \\
\hline & Link the scholarship to the attendance rate & $104(20.8)$ \\
\hline & Arrange course time more reasonable & $289(57.9)$ \\
\hline & Select teachers more excellent & $65(13)$ \\
\hline \multirow{4}{*}{ Teachers } & $\begin{array}{c}\text { There is nothing that teachers need to and they have done good jobs in } \\
\text { teaching }\end{array}$ & $48(9.6)$ \\
\hline & $\begin{array}{c}\text { They should be more humorous and help us understand some obscure } \\
\text { contents }\end{array}$ & $317(63.5)$ \\
\hline & $\begin{array}{c}\text { They are expected to explain thoroughly to consolidate our theoretical } \\
\text { foundation }\end{array}$ & $32(6.4)$ \\
\hline & $\begin{array}{l}\text { They should contact the teaching contents with practice and communicate } \\
\text { more with the students }\end{array}$ & $102(20.4)$ \\
\hline \multirow{4}{*}{ Students } & Students do not need to do anything because it is not what we can change & $29(5.8)$ \\
\hline & $\begin{array}{l}\text { Develop good life and study habits in order to adapt to the school } \\
\text { curriculum }\end{array}$ & $208(41.7)$ \\
\hline & Change ideas and pay attention to every class & $104(20.8)$ \\
\hline & Learn to arrange the time to avoid the conflict of all kinds of activities & $158(31.7)$ \\
\hline
\end{tabular}

It can be seen from the Table 5 that, in order to reduce truancy, $57.9 \%$ of the students stated that the school should arrange course time more reasonable;20.8\% of the students argued that the school 
should link scholarships to attendance rate; $13 \%$ of the students suggested that the school should sift teachers more excellent;8.2\% of the students believed that the school should introduce a series of measures more severe; $63.5 \%$ of the students thought that teachers should be more humorous and help students understand some obscure contents;20.4\% of the students thought that teachers should connect what they teach with the practice and communicate more with the students; and other students stated that teachers should explain deeply to consolidate students' theoretical foundation.9.6\% of the students held that teachers do not need to make changes because they have taught very well; $41.7 \%$ of the students stated that they should keep good life and study habits, so as to adapt to the school curriculum arrangement;31.7\% of the students believed that they should learn to arrange their time reasonably to avoid the conflict of various activities.20.8\% of the students argued that students should change their ideas and pay attention to every class;5.8\% of the students thought that the phenomenon of students skipping classes is not a thing they can change and thus they do not need to do anything. Thus a conclusion can be drawn from the analysis above that, to reduce the rate of students skipping classes, most students think that the school should introduce reasonable arrangement of course time, while teachers should be humorous and help them understand some obscure contents; and at the same time, students should develop good habits of life and learning to adapt to the school's curriculum; only few students believe that their own efforts do not work on the improvement of phenomenon of truancy.

\section{Attribution Analysis}

\subsection{The Attribution Theory of Heider}

Fritz Heider, a psychologist, believed that people have two strong basic needs: one is the need for a consistent understanding of the surrounding environment, and the other is the need for the control of the environment. Action is formed by the interaction of human power and environmental force. If the human power is greater than the environmental force, it will make attribution to people (internal attribution); if the strength of environment is stronger than that of human, it will make attribution to environment (external attribution).Based on Haider's Attribution Theory as well as the internal attribution and external attribution, it can be seen clearly that the truancy of students in Southwest Medical University tends to the internal attribution:52.7\% of the students thought the teachers' teaching was too boring to attract them; $34.1 \%$ of the students skipped class because the teachers didn't call the roll, and thus they thought it would be okay if they didn't attended the class; $19.4 \%$ of the students took oversleeping as the reason for playing truant from classes. When the students conducted the external attribution, the difficulty of the courses became the main reason.26.1\% of the students thought the courses were too simple and thus it was not necessary to attend classes, while $20.8 \%$ of the students stated that the courses were too difficult to catch up with and they did not have any interest in them, and thus so they skipped classes as others did; $10.2 \%$ of the students took weather as the reason for truancy. In this connection, we have a prediction: the truancy rate of a course can be reduced to a certain extent, if this course is moderately difficult while the teacher teaches in a humorous and interesting way and checks class attendance properly.

\subsection{Correspondent Inference Theory of E.E. Jones and K.E. Davis}

In general, we can deduce the intrinsic characteristics (abilities) or psychological tendencies corresponding to a person according to special information such as behaviors. Jones and Davies believed that the purpose of attribution is to infer the conclusion that behavior and intention of the behaviors are consistent with some basic and stable characteristics of the person, namely, a conclusion consistent or corresponding with human's internal tendency. From this perspective, we received a conclusion: how students perceive the behavior of skipping classes is related to whether they will skip classes or not; whether students like their specialty is related to whether they will skip classes or not; whether students think truancy will affect the improvement of their professional knowledge and comprehensive ability is related to whether they will skip classes or not; and students' psychology after skipping classes is also related to whether they will skip classes or not. 
In addition, Jones and Davies also put forward the concept of social desirability, that is, the extent to which action meets the demands of the society. We objectively think that students should not play truant -- this is the behavior that meets the desire of society. The social desirability will influence the corresponding reasoning of people. For example, a student has a strong desire to skip a class, but the student chooses to give up playing truant because he thinks students should not skip classes due to the influence of social desirability. It can be seen here that the behavior that conforms to the social desirability does not tell the student the intrinsic tendency of himself.

\subsection{Kelly's Three-Dimension Model}

The social psychologist Kelly pointed out in the Three-dimensional Attribution Theory that the cause of any event can be divided into three aspects: actors, stimulus objects and context. The attribution analysis of truancy based on the Three-dimension Theory can be interpreted as: students themselves -- such as lack of interest in learning, the cognitive deviation of truancy behavior, indolence, lack of interest in specialty, poor ability of self-control, work of student cadres, etc; objective phenomena -- such as attraction of truancy to students, weather, unreasonable curriculum, unimportant curriculum, unattractive teachers, emergency needing to be solved promptly, etc; context -- such as the transition from the high school student to the college student, conformity behavior caused by the popularity of truancy in schools, the severe employment situation, etc.

\subsection{Self-Perception Psychology of D.J. Bem}

Bem highlighted how people deduce their own reactions, emotions and attitudes. When an individual wants to know his own attitudes, emotions and other internal states, he arrives at his conclusion partly by inferring his behaviors and the environment in which he observes his explicit behaviors. Students play truant from a class because they deduce that they have already played truant by observing their explicit behavior that they do not attending a class without asking for leave and any reason and this behavior occurs during the time of the class.

\subsection{Focus of Control of J.B. Rotter}

The Locus of Control (Focus of Control) is considered to be a generalized expectation of the relationship between the personal character and behavioral outcome. This theory emphasizes that there are some stable individual differences between percipients, and these individual differences affect the causal inference. There are some differences in the view of skipping classes, which leads to different attitudes of students: $76.6 \%$ of the students believed that the behavior of skipping classes was understandable in some cases, while $4 \%$ of the students were opposed to truancy in any case. We can use Rotter's theory to analyze the reasons for the phenomenon of students skipping classes: some students attributed the behavior of skipping classes to the curriculum setting -- they thought the courses were too difficult or too simple to meet their needs and so they chose to play truant from classes; some students attributed students skipping classes to teachers whose lectures were boring, and they thought that teachers never called roll and thereby they skipped classes because their attendance did not affect their final scores; other students did not want to go to class because they overslept or because of the weather. These individual differences lead to different deductions of students' truant behavior.

\section{Discussion}

\subsection{The Basic Features of the Research Objects}

Taking 1000 freshmen of the Southwest Medical University as the research objects, the data showed that the gender was significantly related to the phenomenon of skipping classes. The 1000 samples were covered students from 11 specialties (including medical specialties and non-medical specialties), and the result also showed that the specialty category was significantly related to students skipping classes. 


\subsection{The Idea of Freshmen to Truancy}

\subsubsection{The Relationship Between Truancy and Attribution}

Among the freshmen involved in the survey, elective courses held the highest truancy proportion while specialized courses got the lowest. This may be closely related to the importance that students attach to the courses, but the most important reasons are as follows:

(1) To the question "do you skip classes because the teacher's lecture is too boring to attract you attention", 52.7\% of respondents selected the answer "Yes". It is thought-provoking that more than half of the freshmen chose this option. Is it really too boring or only because they do not want to try it? According to the survey result, the elective courses held the highest truancy rate while specialized courses got the lowest. Is the phenomenon of large-scale truancy really because the elective courses are boring? And what did those students think of when they selected their elective courses?

(2) To the question "do you skip classes because the teacher never call the roll and thus it does matter whether you attend the class or not", 34\% respondents chose the answer "Yes". A lot of students play truant from classes again and again with a fluke mind.

(3) To the question "do you skip classes because the course is too simple to attend classes", $26.1 \%$ respondents selected the answer "Yes".

\subsubsection{Attitude After Truancy}

According to the result of this survey, more than $40 \%$ of the students would feel guilty and tension after skipping classes; $35.5 \%$ of the students said they didn't think much after skipping classes; $18.2 \%$ of the students showed that they would play truant from classes next time though they felt guilty after skipping classes; Therefore, in a certain context and to a certain extent, here can get some viewpoints:

The freshmen have a feeling of guilt and tension about their truancy, which shows that most freshmen reflect on themselves and are not willing to play truant in their deep hearts.

Some students did not think much after skipping classes, indicating that they may have developed the habit of skipping classes. This may be because they may have too few restraints on their truancy behavior and their self-awareness is not high enough.

\subsection{Aspects Needing to Be Improved in This Research}

The design of questionnaire: based on related theories, the questionnaire is compiled by referencing to others' questionnaires. The reliability and validity of the questionnaire are not as good as other questionnaires, which is an aspect of the questionnaire needing improvement.

This research mainly focuses on the attribution analysis of truancy phenomenon from the perspective of students, and the attribution analysis from the perspective of teachers can be highlighted in future research.

The questionnaire survey was mainly carried out in the north campus of the school, leading to the uneven distribution of campuses in the whole survey. The psychological attribution analysis of truancy focuses on students in science departments while students of liberal arts are few. There are certainly some differences between different disciplines in classroom teaching behaviors, which were ignored in this research.

The focus of this research laid stress on exploring the status quo and influencing factors of the psychological attribution analysis of college Students skipping classes. Furthermore, the truancy of students also affect their academic performance and development in various aspects, which can be taken as the direction of future research, such as the relationship between college Students' psychological attribution of truancy and employment, the relationship between truancy and mental health of college students, and so on.

\section{Conclusion}

Truancy is ubiquitous in universities; 2) elective courses hold the highest truancy rate; 3) students usually do other jobs after skipping classes; 4) the phenomenon of students skipping classes is related to the school, teachers, students themselves and other factors; 5) students hope that the school, teachers and themselves can make efforts together to reduce truancy. 
Method: In this paper, a quantitative sampling method will be used to investigate 1000 students in Southwest Medical University, and SPSS 21.0 will be employed for statistical analysis.

Result: According to the data of the questionnaire survey, only $8.8 \%$ of the students never skipped classes; the truancy from elective courses got the highest proportion, up to 58.5\%;After skipping classes, $55.1 \%$ of the students chose to do their proper work; the correlation coefficient between professional and truancy is -0.127 ; the correlation coefficient between gender and truancy is -0.095 ; the correlation coefficient between the favor on specialty and the corresponding truancy is $-0.094 ; 57.9 \%$ of the students expected the school to arrange courses more reasonable; $63.5 \%$ of the students hoped that the teacher should be more humorous and help students understand some obscure contents; $41.7 \%$ of the students stated that they should keep a good life and study habits, so as to adapt to the school curriculum arrangement.

\section{Acknowledgments}

This paper is one of the series of papers to the Innovation and Entrepreneurship Training Program of Luzhou Medical College Students (No.: 2015016), namely, "Psychological Attribution Analysis of Medical Students Skipping Classes”.

\section{References}

[1]. Tian Lin, Yuan Hangde. On Psychology of College Students Skipping Classes [J]. Moral Education, 2013 (9): 53.

[2]. Zhang Xu. Study on the Status and Influencing Factors of College Students' Participation in Class [D]. Suzhou: Soochow University, 2014.

[3]. Yu Yong Gang. The problem of College Students Playing Truant from Ideological and Political Theory and the Countermeasures [D]. Shanghai: Huazhong University of Science and Technology, 2008.

[4]. Ni Jianjun, Bu Jingqiong. Psychological Analysis of College Students Skipping Classes and Countermeasures [J]. Education and Research, 2008 (10): 40-41.

[5]. Li Jie, Wang Xiongxiong. Research on the Phenomenon of College Students' Skipping Lessons [J]. China Youth Study, 2006 (1): 77-79.

[6]. Meng Fanna. Research on the Significance Obstacle of College Students' Truant Behavior and Education Intervention [D]. Chongqing: Southwestern University, 2011.

[7]. Lang Jia. Study of College Students' Recessive Truancy [D]. Chongqing: Southwestern University, 2009.

[8]. Lu Ying. Interpretation of College Student Skipping Classes from the Perspective of students [D]. Shantou: Shantou University, 2008.

[9]. Zhang Haidi. A study on the Truancy problem of Graduating Classes students in General Colleges -- Taking H University as an Example [D]. Hebei: Hebei University, 2012.

[10]. Jin Jingjing. A study of College Students' Truant Behavior from the Perspective of Cognitive Behavior Theory [D]. He'nan: He'nan Normal University, 2011.

[11]. Chen Gang. The Behavioral Dynamics Analysis and Countermeasures of College Students Playing Truant from Classes [J]. China Youth Study, 2005, (8):86 - 88.

[12]. Qiu Xi. Self-attribution of College Students Skipping Classes [J]. Journal of Mianyang Normal University, 2005, (4):74 -79. 
[13]. Qiao Ying. Causes and Countermeasures of College Students Skipping Classes [J]. China Higher Education Research, 2006, (3):86 - 88.

[14]. Yin Haiyan. The Causes of College Students Skipping Classes and Influencing Factors and Countermeasures of This Phenomenon [J]. Journal of Guangxi Teachers Education University (PHILOSOPHY AND SOCIAL SCIENCE EDITION), 2007, (10):30 - 35.

[15]. Zhao Xinfeng. The Particularity of Higher Education Contract and the Analysis of College Students' Truancy Behaviors [J]. Journal of Xi'an University of Arts and Science (SOCIAL SCIENCE EDITION), 2006, (1):87 - 90.

[16]. Zhou Qi. The Deviation Between the Goal and the Means -- Sociological Analysis of College Students' recessive Truancy [J]. Contemporary Youth Research, 2001, (3):16 - 17.

[17]. Zeng Hong. The Relationship between College Students' recessive Truancy and Personality Characteristics and Core Self-evaluation [J]. Chinese Journal of School Health, 2011, (7):793 794.

[18]. Cheng Shuhua. The Strategy of "Silence” and "Truancy" in College Classes [J]. Heilongjiang Researches on Higher Education, 2009, (7): 94 - 96.

[19]. Wang Changmin. Innovation of Seat Management System With the purpose of Rooting up Truancy [J]. Heilongjiang Researches on Higher Education, 2009, (6):43 - 45.

[20]. Li Shiping. College Students' Truancy and the Reform of College Education System [J]. China Adult Education, 2007, (2):50 - 51. 